\title{
Ophthalmologica
}

Ophthalmologica 2019;242:187-194

DOI: 10.1159/000500574
Received: February 12, 2019

Accepted after revision: April 25, 2019

Published online: July 5, 2019

\section{Inherited Retinal Disorders: Using Evidence as a Driver for Implementation}

\author{
Panagiotis I. Sergouniotis ${ }^{\mathrm{a}-\mathrm{c}}$ \\ ${ }^{a}$ Division of Evolution and Genomic Sciences, Faculty of Biology, Medicine and Health, University of Manchester, \\ Manchester, UK; ${ }^{\mathrm{b}}$ Manchester Centre for Genomic Medicine, Saint Mary's Hospital, Manchester University NHS \\ Foundation Trust, Manchester, UK; ' ${ }^{C}$ Manchester Royal Eye Hospital, Manchester University NHS Foundation Trust, \\ Manchester, UK
}

\section{Keywords}

Inherited retinal disease $\cdot$ Rare eye disease $\cdot$ Clinical utility · Evidence-based medicine · Genomic medicine · Implementation science

\section{Abstract}

Incremental advances in the field of retinal genetics have transformed our understanding of inherited retinal disorders and have led to the development of powerful diagnostic tests and promising gene-based therapies. Despite this, successful integration of these developments into routine healthcare is frequently ineffective. Providing robust evidence of benefit can accelerate the implementation of clinical genetic interventions. For example, the adoption of a genetic test is much more likely when the test's clinical utility (i.e. its ability to influence management and health outcomes) has been clearly demonstrated. However, accruing such evidence for rare conditions like inherited retinal disorders is challenging. Conducting sufficiently powered studies requires both efficient study designs and large-scale, international collaboration. Reaching all populations and as many affected individuals as possible is key. Equally important are efforts to precisely and consistently capture pheno- typic information, including natural history data. This article summarizes some of the current obstacles to implementation and discusses approaches to overcome these barriers.

(c) 2019 S. Karger AG, Basel

Susceptibility to human diseases is typically influenced by the complex interplay between genetic, environmental/lifestyle and stochastic factors. The relative contribution of genetic alterations to disease predisposition is variable, and genetic disorders form a continuum: on the one end of the spectrum are common conditions (e.g. age-related macular degeneration and diabetic retinopathy) that are influenced by multiple factors to the degree that the direct effect of individual genetic changes is blurred; on the other end of the spectrum, there are conditions like rod-cone dystrophy, for which the identification of defects in a single gene can predict disease development with relatively high accuracy (Fig. 1) [1-3]. The term monogenic or Mendelian is used to describe the latter group of disorders. Although each individual condition in this group is rare (defined in the $\mathrm{EU}$ as affecting less than 1 in 2,000 individuals [4]), collectively they are common, and their cumulative impact on affected fami-

\section{KARGER}

(c) 2019 S. Karger AG, Basel

E-Mail karger@karger.com

www.karger.com/oph
Panagiotis I. Sergouniotis, FRCOphth, $\mathrm{PhD}$

Manchester Royal Eye Hospital

Oxford Road

Manchester M13 9WL (UK)

E-Mail panagiotis.sergouniotis@ manchester.ac.uk 
Fig. 1. Spectrum of inherited disorders on the basis of heritability and genetic complexity. Monogenic disorders like Sorsby fundus dystrophy are highly heritable and have a simple genetic aetiology; in these conditions, alterations in a single gene are responsible for most of the disease risk (with possible minor contributions of modifier genes or environmental factors). In multifactorial disorders like age-related macular degeneration, multiple variants, each with a relatively small effect, contribute to disease risk along with environmental and lifestyle factors [54, 55].

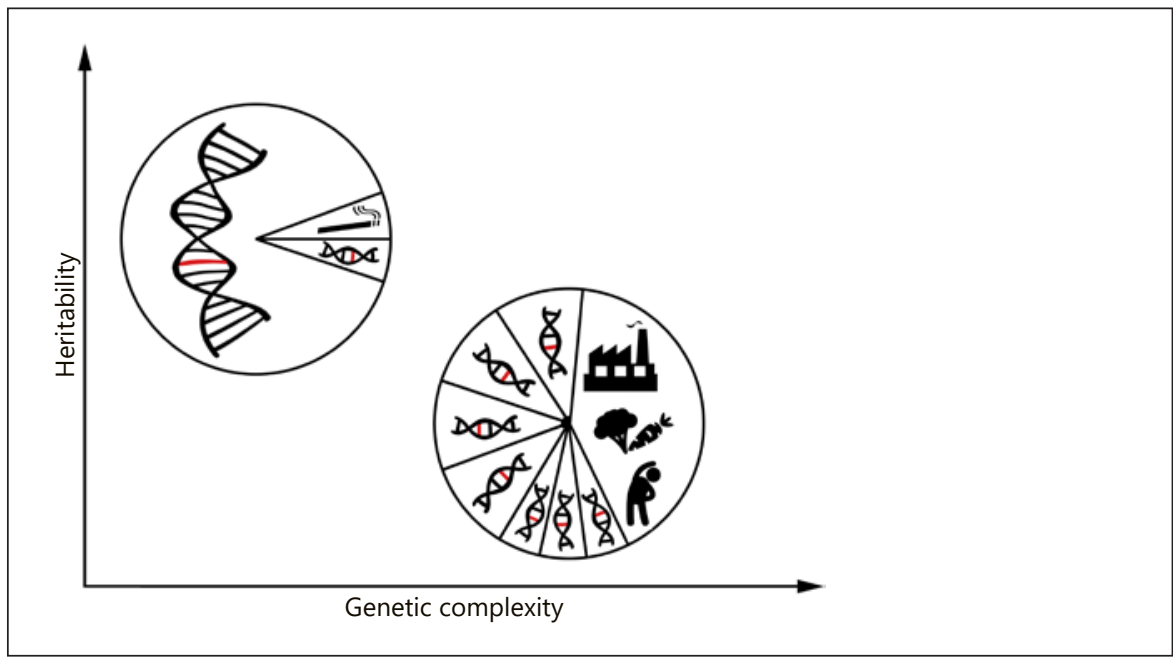

Fig. 2. Graph showing the number of genes reported to be linked to inherited retinal disorders (IRDs) over time (modified from [13]). The first four genes to be described/ cloned are highlighted (RB1 [7], OAT [9], RHO [10], CHM [11]). Four additional genes associated with particularly prevalent IRD subtypes are also shown (PRPH2 [56, 57], RPGR [58], ABCA4 [59], USH2A [60]). The two major highlights in the field of genomics over the past three decades are indicated [61-68]. The author significantly contributed to the discovery of the IRD-associated genes in white [69-74].

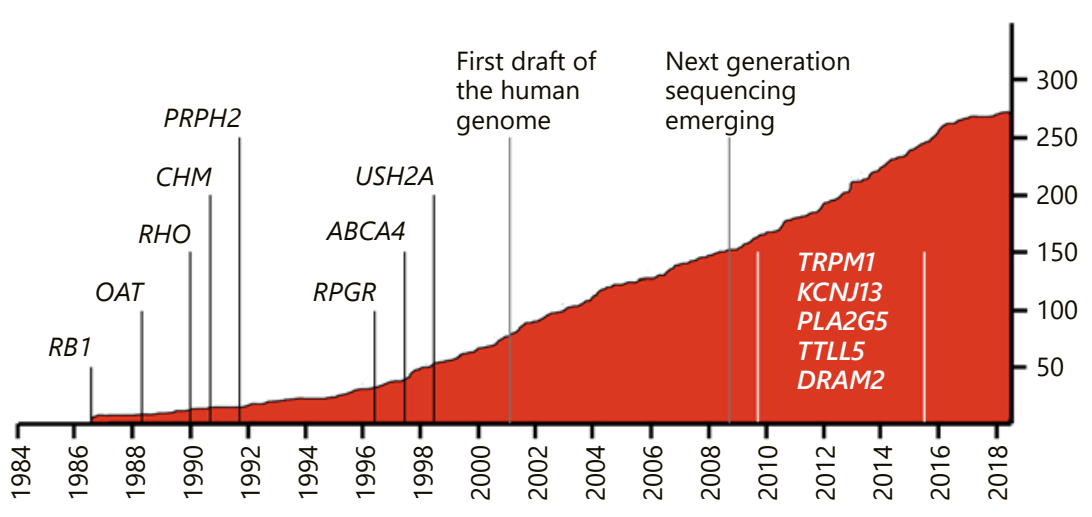

lies and healthcare systems is substantial $[5,6]$. This article focuses on monogenic retinal disorders and discusses the importance of building a strong evidentiary foundation for genetic ophthalmology.

The modern era of retinal genetics began in 1986 with the identification and cloning of RB1, the gene associated with retinoblastoma $[7,8]$. Two years later, mutations in the OAT gene were found to cause gyrate atrophy [9] and, in 1990, the rhodopsin (RHO) gene was linked to dominant rod-cone dystrophy [10] and the CHM gene was linked to choroideremia $[11,12]$. In the three decades that followed these early breakthroughs, over 270 genes have been associated with retinal disorders (Fig. 2) [13]. These discoveries have ushered a new era for the field of retinal genetics and catalysed the development of powerful genomic tests that have revolutionised diagnostics for monogenic retinal disease $[14,15]$. It has also been possible to translate this growing genomic knowledge into targeted interventions. Notable examples include gene augmentation therapies [16], anti-sense oligonucleotide treatments [17] and pre-implantation genetic screening [18].

Contemplating such progress is gratifying, but the challenges lying ahead remain considerable. A central problem is that of integrating research findings into healthcare practices and policies [19-21]. Important considerations include the cost, the benefit and the evidentiary basis of each proposed intervention. Genetic testing is discussed here as an example: although the importance and value of genetic testing for monogenic retinal disorders has been repeatedly highlighted over the past decades [22-24], variation in the current provision of testing remains significant $[25,26]$. Considering economic factors is necessary but insufficient. Two important questions that need to be answered are how beneficial are these tests and how strong is the evidence that supports their routine use? 
Table 1. Glossary

\begin{tabular}{ll}
\hline Genetics & The study of genes, genetic variation, and heredity in living organisms [27, 75] \\
\hline Genomics & The study of genomes; the term genome refers to all the nucleotide sequences \\
(including genes, regulatory sequences, and noncoding DNA segments) that are \\
found in an organism, tissue sample or cell; genomics includes the study of not only \\
single genes, but also of the functions and interactions of all the genes in a genome \\
{$[27,76,77]$}
\end{tabular}

Genetic testing A type of medical test that aims to identify changes in DNA, RNA, chromosomes or proteins; it can be performed for diagnostic, predictive or reproductive purposes. Diagnostic testing aims to identify, rule out or confirm the diagnosis of a suspected inherited condition.

Predictive testing aims to identify changes associated with increased risk of developing an inherited disorder before any symptoms or signs appear; this includes population screening, such as newborn screening. Reproductive testing aims to identify people who are at increased risk of having a child with a genetic disorder or to identify an affected embryo or fetus; this includes carrier testing, prenatal genetic testing, and pre-implantation testing.

Different methods for assessing the validity and usefulness of a genetic test have been described, but the three principle measures are: analytic validity, clinical validity, and clinical utility. Importantly, each genetic test evaluation should start by defining the clinical scenario for testing (including the target condition, the target population and the purpose of the test); for example, the validity and usefulness of a genetic test for Usher syndrome will be different if the target population includes all newborn children or if it includes just individuals with combined rod-cone dystrophy and hearing loss [27]

Analytical validity The ability of a test to accurately and reliably identify the specific entity that it was designed to detect (e.g. a genetic variant of interest); it often reflects the robustness of the assay and it is typically described in terms of analytical sensitivity (i.e. how often the test is positive when a variant is known to be present) and analytical specificity (i.e. how often the test is negative when a variant is known to be absent); notably, a test will not be considered suitable for clinical use unless it meets acceptable standards for analytic validity $[27,81]$

Clinical validity The ability of a test to accurately and reliably identify a clinically defined disorder or phenotype of interest; it corresponds to the diagnostic yield, accuracy or pick-up rate and it is typically described in terms of sensitivity (i.e. how often the test is positive when a condition is present) and specificity (i.e. how often the test is negative when a condition is not present) $[27,82]$

Clinical utility The ability of a test to influence clinical outcomes and patient management; it evaluates the health benefits and potential harms that accrue from both positive and negative results of the test; it often reflects the utility of the intervention guided by the test rather than the test itself; narrow and broad sense definitions have been described - please see the main text for further details [27, 30-32, 81-84] 
Table 1 (continued)

\begin{tabular}{ll}
\hline Clinical actionability & $\begin{array}{l}\text { The ability to intervene and thereby avert a poor outcome due to a previously } \\
\text { unsuspected high risk of disease; it is often used in the context of secondary/ } \\
\text { incidental genetic findings in certain genes that, when significantly altered, confer a } \\
\text { high risk of serious disease that could be prevented or mitigated [85-87] }\end{array}$ \\
\hline Clinical trial & $\begin{array}{l}\text { A study carried out according to a prospectively defined protocol that is intended to } \\
\text { discover or verify the safety and effectiveness of a procedure or intervention [27] }\end{array}$ \\
\hline $\begin{array}{l}\text { Evidence-based } \\
\text { medicine }\end{array}$ & $\begin{array}{l}\text { The conscientious, explicit and judicious use of current best evidence in making } \\
\text { decisions about the care of individual patients; it integrates clinical experience and } \\
\text { patient values with the best available research information [88, 89] }\end{array}$ \\
\hline $\begin{array}{l}\text { Genomic medicine } \\
\text { A medical discipline that involves using genomic information about an individual as } \\
\text { part of their clinical care [90, 91] }\end{array}$ \\
$\begin{array}{ll}\text { Precision medicine } & \text { An approach to disease treatment and prevention that takes into account individual } \\
\text { variability in environment, lifestyle and genes; the terms precision medicine and } \\
\text { personalised medicine are often used interchangeably [92-95] }\end{array}$ \\
$\begin{array}{l}\text { Implementation science } \\
\text { (healthcare) }\end{array}$ & $\begin{array}{l}\text { The study of methods to promote the integration of research findings and evidence } \\
\text { into healthcare policy and practice [19, 20, 96] }\end{array}$ \\
\hline
\end{tabular}

In 2017, the US National Academies of Sciences, Engineering, and Medicine released a report titled "An Evidence Framework for Genetic Testing" [27]. This document discusses the clinical applications and usefulness of genetic tests, and examines how relevant evidence is generated, evaluated and synthesised. A key concept in this report is that of clinical utility defined as "the ability of a test to improve clinical outcomes measurably and to add value for patient management decision making compared with current management without genetic testing" $[27,28]$. This term has been used in the context of genetic testing for over 20 years and, over this period, it has been construed both narrowly and broadly [29-31]. Scholars who refer to clinical utility by its narrowest definition focus on the ability of a screening or a diagnostic test to lead to an improved health outcome (impact on mortality, morbidity, disability; e.g. excising a Wilms tumour detected following a genetic test for aniridia). Conversely, broader definitions may include any change in management (e.g. preventing additional investigations or introducing personalised surveillance measures) or any outcome that is important to the affected individual or family (e.g. early resolution of uncertainty, better understanding of condition, effect on reproductive or life planning) [31]. It is noteworthy that other test parameters such as analytical validity (i.e. the ability to accurately identify variants of interest) and clinical validity (i.e. the diagnostic accuracy) are related but not overlapping with clinical utility (Table 1). Also, clinical utility is not tied to cost-effectiveness as the latter can be only evaluated at the site level. At present, rigorous evidence on the clinical utility of genetic testing for monogenic retinal disorders is lacking - as indeed it is lacking for most other monogenic disorders (i.e. it is unclear who should be tested, with what test and when). Notably, there is no consensus on what constitutes sufficient evidence to justify implementation of genetic testing - are randomised trials required, or can observational studies aligned to mechanistic reasoning suffice? Clearly, randomised trials are expensive and hard to justify if there is no genuine uncertainty among experts (principle of equipoise) [32]. In any case, evidence gaps need to be identified and addressed.

Conducting clinical research/trials in rare disorders like monogenic retinal disease poses unique challenges. A key issue is how to avoid conducting underpowered studies. Two evident obstacles are disease heterogeneity and geographic dispersion of affected individuals. The paucity of natural history data poses another important barrier; without a firm understanding of disease progression, choosing meaningful outcome measures and designing and powering clinical trials is challenging [33-36]. Furthermore, many monogenic retinal disorders primarily affect children adding further complexity to potential study design [34]. It is apparent that to overcome these hurdles, stakeholder engagement at an unprecedented level will be required [37].

In recent years, several initiatives have focused on improving our ability to conduct research on rare diseases in general and on monogenic retinal disorders in particular. A notable example is the European Reference Net- 
Table 2. Examples of measures that could accelerate the translation of our growing genetic knowledge into effective interventions for inherited retinal disease (IRD)

Data collection

Harmonising the collection

of phenotypic data

Reduction of unnecessary heterogeneity can be facilitated by:

- the wider adoption of standardized terminologies/ontologies (like HPO [39]);

- $\quad$ supporting a guideline development group that would define a "minimum clinical dataset" (i.e. the specific phenotypic information that should be collected in all individuals with IRD).

Developing a health informatics infrastructure to capture and exchange data
The establishment of a multicenter, international IRD database/registry that includes variant- and individual-level data would require:

- addressing the associated ethical and legislative issues, and navigating the relevant country-specific regulatory barriers;

- adopting standards for responsible, accountable and transparent sharing of clinical-grade data (e.g. as per GA4GH [21]).

\section{Evidence generation}

Facilitating timely and adequate recruitment of eligible clinical trial participants
The prevalence and heterogeneity of IRD makes obtaining sufficient sample sizes for research challenging; addressing this would require:

- reaching as many affected individuals as possible and actively encouraging their recruitment in international registries and research cohorts;

- incentivising and promoting a model of large-scale international collaboration.
Optimising clinical trial design
Incomplete understanding of disease natural history is common in rare diseases like IRD. When natural history data is lacking, choosing appropriate outcomes and designing and powering clinical trials is particularly challenging [34]; addressing this would require.

- $\quad$ promoting and supporting high-quality natural history studies; longterm grants ensuring continuity in these efforts would be required.

- organising interactive workshops that would initiate a multistakeholder dialogue around clinical endpoints and outcome measures that are both sensitive and patient-centred [34-36].

\section{Education}

Increasing workforce

capacity and capability
Initiatives should be taken to expand the workforce of professionals that are trained to understand/incorporate genetics into the care of individuals with IRD; courses and other educational resources that can be broadly accessed should be developed.

Building public trust in genetic research and its clinical application is paramount; potential genetic privacy risks should be appreciated and particular care should be taken to avoid misinterpretation and misuse of scientific results. work on Rare Eye Diseases (ERN-EYE), an initiative with a leading role in the development of key infrastructure such as international patient registries and computational tools to standardise terminology $[38,39]$. Another example is a forum/workshop organised by the Association for Research in Vision (ARVO) and Foundation Fighting Blindness in 2016 with the goal of identifying appropriate trial endpoints for inherited retinal disorders [40]. Outside ophthalmology, substantial efforts have been put on rethinking clinical trial design for small populations, de- fining core sets of patient-centred outcome measures, optimising error rates when there are constraints on the available sample size and identifying models of "realworld" evidence collection [33, 35-37, 41-43]. However, a standardised framework integrating all these elements is still missing.

In December 2017, the US Food and Drug Administration (FDA) in a landmark decision approved the first gene augmentation therapy for an inherited disorder. The drug was voretigene neparvovec, and it can be used to 
treat $R P E 65$-associated retinal dystrophy in adults and children [44]. In November 2018, approval by the European Medicines Agency (EMA) was also obtained, and many European countries are presently conducting Health Technology Assessments to decide whether the therapies should be approved for reimbursement $[45,46]$. Numerous other gene therapies are presently under development or undergoing benefit-risk assessment. There is little doubt that some of these ongoing trials will demonstrate safety and efficacy. However, how many will meet the required standards of evidence for reimbursement bodies remains to be determined [47]. Nonetheless, it only is by conducting high-quality trials and by gathering as robust evidence as possible that we can resolve clinical agnosticism and ensure a significant impact [48].

To obtain sufficient sample sizes for research, we need to engage geographically, socially and economically diverse patient populations. To reach as many affected individuals as possible, the effort of all ophthalmologists who see patients with monogenic retinal disorders will be required. A few steps that could accelerate the translation of our growing genetic knowledge into effective interven- tions include: (i) ensuring that all individuals with monogenic retinal disorders that come to medical attention receive an accurate diagnosis [49]; (ii) capturing clinical information efficiently $[14,50]$ and collecting natural history data in a rigorous and systematic way (e.g. in registries [51]); (iii) appreciating the statistical challenges and focusing on optimising research designs [33-36, 52, 53] (Table 2).

\section{Acknowledgements}

I have been most fortunate to work with so many generous and gifted people over the years. I am especially grateful to my mentors Graeme Black, Andrew Webster and Tony Moore. This work is partly supported by the UK National Institute of Health Research (NIHR) Clinical Lecturer Programme (CL-2017-06-001).

\section{Disclosure Statement}

The author has no conflicts of interest to declare.

\section{References}

1 Wright AF, Chakarova CF, Abd El-Aziz MM, Bhattacharya SS. Photoreceptor degeneration: genetic and mechanistic dissection of a complex trait. Nat Rev Genet. 2010 Apr;11(4): 273-84.

2 Warwick A, Lotery A. Genetics and genetic testing for age-related macular degeneration. Eye (Lond). 2018 May;32(5):849-57.

3 Verbakel SK, van Huet RA, Boon CJ, den Hollander AI, Collin RW, Klaver CC, et al. Nonsyndromic retinitis pigmentosa. Prog Retin Eye Res. 2018 Sep;66:157-86.

4 The European Parliament and the Council of the European Union. Regulation (EC) No $141 / 2000$ of the European parliament and of the council of 16 December 1999 on orphan medicinal products. 1999.

5 Schieppati A, Henter JI, Daina E, Aperia A. Why rare diseases are an important medical and social issue. Lancet. 2008 Jun;371(9629): 2039-41.

6 Walker CE, Mahede T, Davis G, Miller LJ, Girschik J, Brameld K, et al. The collective impact of rare diseases in Western Australia: an estimate using a population-based cohort. Genet Med. 2017;19:546-552.

7 Friend SH, Bernards R, Rogelj S, Weinberg RA, Rapaport JM, Albert DM, et al. A human DNA segment with properties of the gene that predisposes to retinoblastoma and osteosarcoma. Nature. 1986 Oct;323(6089):643-6.
8 Sheffield VC, Stone EM. Genomics and the eye. N Engl J Med. 2011 May;364(20):193242.

9 Mitchell GA, Brody LC, Looney J, Steel G, Suchanek M, Dowling C, et al. An initiator codon mutation in ornithine-delta-aminotransferase causing gyrate atrophy of the choroid and retina. J Clin Invest. 1988 Feb;81(2): 630-3.

10 Dryja TP, McGee TL, Reichel E, Hahn LB, Cowley GS, Yandell DW, et al. A point mutation of the rhodopsin gene in one form of retinitis pigmentosa. Nature. 1990 Jan; 343(6256):364-6.

11 Cremers FP, van de Pol DJ, van Kerkhoff LP, Wieringa $\mathrm{B}$, Ropers $\mathrm{HH}$. Cloning of a gene that is rearranged in patients with choroideraemia. Nature. 1990 Oct;347(6294):674-7.

12 Cremers FP, Boon CJ, Bujakowska K, Zeitz C. Special Issue Introduction: Inherited Retinal Disease: Novel Candidate Genes, GenotypePhenotype Correlations, and Inheritance Models. Genes (Basel). 2018 Apr;9(4):9.

13 Daiger SPRB, Greenberg J, Christoffels A, Hide W. RetNet, the Retinal Information Network. 2019.

14 Stone EM, Andorf JL, Whitmore SS, DeLuca AP, Giacalone JC, Streb LM, et al. Clinically focused molecular investigation of 1000 consecutive families with inherited retinal disease. Ophthalmology. 2017 Sep;124(9):1314-31.
15 Taylor RL, Parry NR, Barton SJ, Campbell C, Delaney CM, Ellingford JM, et al. Panel-based clinical genetic testing in 85 children with inherited retinal disease. Ophthalmology. 2017 Jul;124(7):985-91.

16 Xue K, Jolly JK, Barnard AR, Rudenko A, Salvetti AP, Patrício MI, et al. Beneficial effects on vision in patients undergoing retinal gene therapy for choroideremia. Nat Med. 2018 Oct;24(10):1507-12.

17 Cideciyan AV, Jacobson SG, Drack AV, Ho AC, Charng J, Garafalo AV, et al. Effect of an intravitreal antisense oligonucleotide on vision in Leber congenital amaurosis due to a photoreceptor cilium defect. Nat 2019 Feb; 25(2):225-228.

18 Vermeesch JR, Voet T, Devriendt K. Prenatal and pre-implantation genetic diagnosis. Nat Rev Genet. 2016 Sep;17(10):643-56.

19 Fisher ES, Shortell SM, Savitz LA. Implementation science: a potential catalyst for delivery system reform. JAMA. 2016 Jan;315(4):33940.

20 Chambers DA, Feero WG, Khoury MJ. Convergence of implementation science, precision medicine, and the learning health care system: a new model for biomedical research. JAMA. 2016 May;315(18):1941-2. 
21 Stark Z, Dolman L, Manolio TA, Ozenberger B, Hill SL, Caulfied MJ, et al. Integrating genomics into healthcare: a global responsibility. Am J Hum Genet. 2019 Jan;104(1):13-20.

22 Black GC, Donnai D. Genetic testing-swings and roundabouts: a view from the United Kingdom. Br J Ophthalmol. 2001 Dec;85(12): $1402-4$.

23 Stone EM. Genetic testing for inherited eye disease. Arch Ophthalmol. 2007 Feb;125(2): 205-12.

24 Stone EM, Aldave AJ, Drack AV, Maccumber MW, Sheffield VC, Traboulsi E, et al. Recommendations for genetic testing of inherited eye diseases: report of the American Academy of Ophthalmology task force on genetic testing. Ophthalmology. 2012 Nov;119(11): 2408-10.

25 Retina International. Survey on the current status of the genetic testing for inherited retinal disease. 2018.

26 Harrison M, Birch S, Eden M, Ramsden S, Farragher $\mathrm{T}$, Payne $\mathrm{K}$, et al. Variation in healthcare services for specialist genetic testing and implications for planning genetic services: the example of inherited retinal dystrophy in the English NHS. J Community Genet. 2015 Apr;6(2):157-65.

27 Committee on the Evidence Base for Genetic Testing. National Academies of Sciences, Engineering, and Medicine. An Evidence Framework for Genetic Testing. Washington: National Academies Press; 2017.

28 Teutsch SM, Bradley LA, Palomaki GE, Haddow JE, Piper M, Calonge N, et al: The evaluation of genomic applications in practice and prevention (EGAPP) initiative: methods of the EGAPP Working Group. Genet Med. 2009;11:3-14.

29 Holtzman NA. Promoting safe and effective genetic tests in the United States: work of the task force on genetic testing. Clin Chem. 1999 May;45(5):732-8

30 Grosse SD, Khoury MJ: What is the clinical utility of genetic testing? Genet Med 2006;8: 448-450.

31 Kohler JN, Turbitt E, Lewis KL, Wilfond BS, Jamal L, Peay HL, et al. Defining personal utility in genomics: A Delphi study. Clin Genet. 2017 Sep;92(3):290-7.

32 Bossuyt PM, Reitsma JB, Linnet K, Moons KG. Beyond diagnostic accuracy: the clinical utility of diagnostic tests. Clin Chem. 2012 Dec;58(12):1636-43.

33 Day S, Jonker AH, Lau LP, Hilgers RD, Irony I, Larsson K, et al. Recommendations for the design of small population clinical trials. Orphanet J Rare Dis. 2018 Nov;13(1):195.

34 IRDiRC Small Population Clinical Trials Task Force. Small population clinical trials: challenges in the field of rare diseases. 2016.

35 Whicher D, Philbin S, Aronson N. An overview of the impact of rare disease characteristics on research methodology. Orphanet J Rare Dis. 2018 Jan;13(1):14.
36 Rath A, Salamon V, Peixoto S, Hivert V, Laville M, Segrestin B, et al. A systematic literature review of evidence-based clinical practice for rare diseases: what are the perceived and real barriers for improving the evidence and how can they be overcome? Trials. 2017 Nov; 18(1):556.

37 Boycott KM, Ardigó D. Addressing challenges in the diagnosis and treatment of rare genetic diseases. Nat Rev Drug Discov. 2018 Mar;17(3):151-2.

38 European Reference Network on Rare Eye Diseases (ERN-EYE) [accessed 2019 Feb 5].

39 Sergouniotis PI, Maxime E, Leroux D, Olry A, Thompson R, Rath A, et al.; ERN-EYE Ontology Study Group. An ontological foundation for ocular phenotypes and rare eye diseases. Orphanet J Rare Dis. 2019 Jan; 14(1):8.

40 Csaky K, Ferris F 3rd, Chew EY, Nair P, Cheetham JK, Duncan JL. Report From the NEI/FDA Endpoints Workshop on Age-Related Macular Degeneration and Inherited Retinal Diseases. Invest Ophthalmol Vis Sci. 2017 Jul;58(9):3456-63.

41 Hilgers RD, Roes K, Stallard N; IDeAl, Asterix and InSPiRe project groups. Directions for new developments on statistical design and analysis of small population group trials. Orphanet J Rare Dis. 2016 Jun;11(1):78.

42 Ioannidis JP, Hozo I, Djulbegovic B: Optimal type I and type II error pairs when the available sample size is fixed. J Clin Epidemiol. 2013;66:903-910 e902.

43 Amendola LM, Berg JS, Horowitz CR, Angelo F, Bensen JT, Biesecker BB, et al.; CSER consortium. The Clinical Sequencing EvidenceGenerating Research Consortium: Integrating Genomic Sequencing in Diverse and Medically Underserved Populations. Am J Hum Genet. 2018 Sep;103(3):319-27.

44 US Food \& Drug Administration. FDA approves novel gene therapy to treat patients with a rare form of inherited vision loss. 2017.

45 European Medicines Agency. Luxturna (voretigene neparvovec). 2018.

46 Retina International. Statement from Retina International on the EMA decision to approve Luxturna. 2018.

47 Zimmermann M, Lubinga SJ, Banken R, Rind D, Cramer G, Synnott PG, et al. Cost utility of voretigene neparvovec for biallelic RPE65mediated inherited retinal disease. Value Health. 2019 Feb;22(2):161-7.

48 Carlisle B, Federico CA, Kimmelman J. Trials that say "maybe": the disconnect between exploratory and confirmatory testing after drug approval. BMJ. 2018 Mar;360:k959.

49 Austin CP, Cutillo CM, Lau LP, Jonker AH, Rath A, Julkowska D, et al.; International Rare Diseases Research Consortium (IRDiRC). Future of Rare Diseases Research 2017-2027: An IRDiRC Perspective. Clin Transl Sci. 2018 Jan;11(1):21-7.
50 Wilkinson MD, Dumontier M, Aalbersberg IJ, Appleton G, Axton M, Baak A, et al. The FAIR Guiding Principles for scientific data management and stewardship. Sci Data. 2016 Mar;3:160018.

51 van Huet RA, Oomen CJ, Plomp AS, van Genderen MM, Klevering BJ, Schlingemann RO, et al.; RD5000 Study Group. The RD5000 database: facilitating clinical, genetic, and therapeutic studies on inherited retinal diseases. Invest Ophthalmol Vis Sci. 2014 Nov;55(11): 7355-60.

52 Senn S. Statistical pitfalls of personalized medicine. Nature. 2018 Nov;563(7733):61921.

53 Khoury MJ. No shortcuts on the long road to evidence-based genomic medicine. JAMA. 2017 Jul;318(1):27-8.

54 Manolio TA, Brooks LD, Collins FS. A HapMap harvest of insights into the genetics of common disease. J Clin Invest. 2008 May; 118(5):1590-605

55 Janssens AC, van Duijn CM. An epidemiological perspective on the future of direct-toconsumer personal genome testing. Investig Genet. 2010 Oct;1(1):10.

56 Farrar GJ, Kenna P, Jordan SA, Kumar-Singh R, Humphries MM, Sharp EM, et al. A threebase-pair deletion in the peripherin-RDS gene in one form of retinitis pigmentosa. $\mathrm{Na}$ ture. 1991 Dec;354(6353):478-80.

57 Kajiwara K, Hahn LB, Mukai S, Travis GH, Berson EL, Dryja TP. Mutations in the human retinal degeneration slow gene in autosomal dominant retinitis pigmentosa. Nature. 1991 Dec;354(6353):480-3.

58 Meindl A, Dry K, Herrmann K, Manson F, Ciccodicola A, Edgar A, et al. A gene (RPGR) with homology to the RCC1 guanine nucleotide exchange factor is mutated in X-linked retinitis pigmentosa (RP3). Nat Genet. 1996 May;13(1):35-42.

59 Allikmets R, Shroyer NF, Singh N, Seddon JM, Lewis RA, Bernstein PS, et al. Mutation of the Stargardt disease gene (ABCR) in age-related macular degeneration. Science. 1997 Sep;277(5333):1805-7.

60 Eudy JD, Weston MD, Yao S, Hoover DM, Rehm HL, Ma-Edmonds M, et al. Mutation of a gene encoding a protein with extracellular matrix motifs in Usher syndrome type IIa. Science. 1998 Jun;280(5370):1753-7.

61 Lander ES, Linton LM, Birren B, Nusbaum C, Zody MC, Baldwin J, et al.; International $\mathrm{Hu}-$ man Genome Sequencing Consortium. Initial sequencing and analysis of the human genome. Nature. 2001 Feb;409(6822):860-921.

62 Venter JC, Adams MD, Myers EW, Li PW, Mural RJ, Sutton GG, et al. The sequence of the human genome. Science. 2001 Feb; 291(5507):1304-51.

63 International Human Genome Sequencing Consortium. Finishing the euchromatic sequence of the human genome. Nature. 2004 Oct;431(7011):931-45.
Inherited Retinal Disorders: Using Evidence as a Driver for Implementation
Ophthalmologica 2019;242:187-194

DOI: 10.1159/000500574 
64 Wheeler DA, Srinivasan M, Egholm M, Shen Y, Chen L, McGuire A, et al. The complete genome of an individual by massively parallel DNA sequencing. Nature. 2008 Apr; 452(7189):872-6.

65 Bentley DR, Balasubramanian S, Swerdlow HP, Smith GP, Milton J, Brown CG, et al. Accurate whole human genome sequencing using reversible terminator chemistry. Nature. 2008 Nov;456(7218):53-9.

66 Wang J, Wang W, Li R, Li Y, Tian G, Goodman L, et al. The diploid genome sequence of an Asian individual. Nature. 2008 Nov; 456(7218):60-5.

67 Fedurco M, Romieu A, Williams S, Lawrence I, Turcatti G. BTA, a novel reagent for DNA attachment on glass and efficient generation of solid-phase amplified DNA colonies. $\mathrm{Nu}-$ cleic Acids Res. 2006 Feb;34(3):e22.

68 Turcatti G, Romieu A, Fedurco M, Tairi AP. A new class of cleavable fluorescent nucleotides: synthesis and optimization as reversible terminators for DNA sequencing by synthesis. Nucleic Acids Res. 2008 Mar; 36(4):e25.

69 Li Z, Sergouniotis PI, Michaelides M, Mackay DS, Wright GA, Devery S, et al. Recessive mutations of the gene TRPM1 abrogate ON bipolar cell function and cause complete congenital stationary night blindness in humans. Am J Hum Genet. 2009 Nov;85(5):711-9.

70 Sergouniotis PI, Davidson AE, Mackay DS, Li $\mathrm{Z}$, Yang X, Plagnol V, et al. Recessive mutations in KCNJ13, encoding an inwardly rectifying potassium channel subunit, cause leber congenital amaurosis. Am J Hum Genet. 2011 Jul;89(1):183-90.

71 Sergouniotis PI, Davidson AE, Mackay DS, Lenassi E, Li Z, Robson AG, et al. Biallelic mutations in PLA2G5, encoding group V phospholipase A2, cause benign fleck retina. Am J Hum Genet. 2011 Dec;89(6):782-91.

72 Sergouniotis PI, Chakarova C, Murphy C, Becker M, Lenassi E, Arno G, et al.; UCLExomes Consortium. Biallelic variants in TTLL5, encoding a tubulin glutamylase, cause retinal dystrophy. Am J Hum Genet. 2014 May;94(5):760-9.
73 El-Asrag ME, Sergouniotis PI, McKibbin M, Plagnol V, Sheridan E, Waseem N, et al.; UK Inherited Retinal Disease Consortium. Biallelic mutations in the autophagy regulator DRAM2 cause retinal dystrophy with early macular involvement. Am J Hum Genet. 2015 Jun;96(6):948-54.

74 Sergouniotis PI, Robson AG, El-Asrag ME, Ali M, Holder GE, Black GC, et al.; UCL Exomes Consortium. UK Inherited Retinal Disease Consortium. Use of a gene-based case-control association approach in exome sequencing data to elucidate the molecular basis of a mendelian phenotype. Lancet. 2017; 389:S14.

75 Harper PS. William Bateson, human genetics and medicine. Hum Genet. 2005 Oct;118(1): 141-51.

76 Kuska B. Beer, Bethesda, and biology: how "genomics" came into being. J Natl Cancer Inst. 1998 Jan;90(2):93.

77 Guttmacher AE, Collins FS. Genomic medicine-a primer. N Engl J Med. 2002 Nov; 347(19):1512-20.

78 Chial H. Mendelian Genetics: patterns of inheritance and single-gene disorders. Nat Educ. 2008;1:63.

79 National Institutes of Health: Rare Diseases Act of 2002. Public Law 107-280, 107th Congress. 2002.

80 Song P, Gao J, Inagaki Y, Kokudo N, Tang W. Rare diseases, orphan drugs, and their regulation in Asia: current status and future perspectives. Intractable Rare Dis Res. 2012 Feb; 1(1):3-9.

81 Javaher P, Kaariainen H, Kristoffersson U, Nippert I, Sequeiros J, Zimmern R, et al. EuroGentest: DNA-based testing for heritable disorders in Europe. Community Genet. 2008;11(2):75-120.

82 Burke W: Genetic tests: clinical validity and clinical utility. Curr Protoc Hum Genet. 2014 Apr 24;81:9.15.1-8.

83 ACMG Board of Directors: Clinical utility of genetic and genomic services: a position statement of the American College of Medical Genetics and Genomics. Genet Med. 2015;17: 505-507.
84 Dotson WD, Bowen MS, Kolor K, Khoury MJ: Clinical utility of genetic and genomic services: context matters. Genet Med. 2016;18:672674.

85 Webber EM, Hunter JE, Biesecker LG, Buchanan AH, Clarke EV, Currey E, et al.; ClinGen Resource. Evidence-based assessments of clinical actionability in the context of secondary findings: Updates from ClinGen's Actionability Working Group. Hum Mutat. 2018 Nov;39(11):1677-85.

86 Hunter JE, Irving SA, Biesecker LG, Buchanan $A$, Jensen $B$, Lee $K$, et al: A standardized, evidence-based protocol to assess clinical actionability of genetic disorders associated with genomic variation. Genet Med. 2016;18: 1258-1268.

87 Richer J, Laberge AM: Secondary findings from next-generation sequencing: what does actionable in childhood really mean? Genet Med 2019;21:124-132.

88 Sackett DL, Rosenberg WM, Gray JA, Haynes RB, Richardson WS. Evidence based medicine: what it is and what it isn't. BMJ. 1996 Jan; 312(7023):71-2.

89 Evidence-Based Medicine Working G; Evidence-Based Medicine Working Group. Evidence-based medicine. A new approach to teaching the practice of medicine. JAMA. 1992 Nov;268(17):2420-5.

90 Feero WG, Guttmacher AE, Collins FS. Genomic medicine-an updated primer. N Engl J Med. 2010 May;362(21):2001-11.

91 National Human Genome Research Institute: Genomic medicine and health care: 2016,

92 Feero WG. Introducing "Genomics and Precision Health”. JAMA. 2017 May;317(18): $1842-3$.

93 Collins FS, Varmus H. A new initiative on precision medicine. N Engl J Med. 2015 Feb; 372(9):793-5.

94 Jameson JL, Longo DL. Precision medicinepersonalized, problematic, and promising. $\mathrm{N}$ Engl J Med. 2015 Jun;372(23):2229-34.

95 Ashley EA. Towards precision medicine. Nat Rev Genet. 2016 Aug; 17(9):507-22.

96 Bauer MS, Damschroder L, Hagedorn H, Smith J, Kilbourne AM. An introduction to implementation science for the non-specialist. BMC Psychol. 2015 Sep;3(1):32. 